JURNAL KETAHANAN NASIONAL

Vol. 26, No. 1, April 2020, Hal 55-70

DOI:http://dx.doi.org/ 10.22146/jkn.52695

ISSN:0853-9340(Print), ISSN:2527-9688(Online)

Online sejak 28 Desember 2015 di :http://jurnal.ugm.ac.id/JKN

VOLUME 26

No. 1, April 2020

Halaman 55-70

\title{
Pasar, Tata Kelola Dan Hubungan Transnasional Di Era Globalisasi Dan Implikasinya Terhadap Ketahanan Politik Dunia
}

\author{
Iskandar Hamonangan \\ Departemen Ilmu Hubungan Internasional \\ Fakultas Ilmu Sosial dan Ilmu Politik, Universitas Indonesia \\ Email: iskandar.hamonangan91@alumni.ui.ac.id
}

\begin{abstract}
This paper discusses globalization and its relation to the markets, global governance and the transnational relations. The author describes globalization as a process of transition to an integrated global society. Globalization is generally associated with the global economy, but the globalization itself has gone beyond economic issues and has challenged to the resilience of global politics. Globalization also involves other issues such as the environment, global warming, and even human rights, which involve not only the state as an actor, but also non-state actors such as non-governmental organizations and civil society who have the possibility of influencing global political development at global level. The author argues that globalization has influenced and has shaped new forms of global political interactions. It can be seen since non-state actors such as non-governmental organizations and civil society can influence a state in making policy decisions.
\end{abstract}

Keywords: Globalization, Governance, Transnationalism, Global Resilience

\begin{abstract}
ABSTRAK
Tulisan ini mendiskusikan globalisasi dan keterkaitannya dengan pasar, tata kelola global dan hubungan transnasional. Penulis menggambarkan globalisasi sebagai suatu proses transisi menuju suatu masyarakat global yang terintegrasi. Globalisasi pada umumnya dikaitkan dengan ekonomi global, namun pemahaman mengenai globalisasi telah melampaui masalah ekonomi dan memiliki tantangan-tantangan terhadap ketahanan politik global. Globalisasi juga melibatkan isu-isu seperti lingkungan, pemanasan global, bahkan hak asasi manusia, yang melibatkan tidak hanya negara sebagai aktor, namun juga aktor-aktor non negara seperti organisasi non-pemerintah dan masyarakat sipil dan memiliki kemungkinan dalam mempengaruhi perkembangan politik dunia secara global. Penulis berpendapat bahwa globalisasi memiliki pengaruh dan telah membentuk interaksi-interaksi politik global yang baru. Hal tersebut dapat dilihat bahwa aktor non negara seperti organisasi non-pemerintah dan kalangan masyarakat sipil dapat mempengaruhi suatu negara dalam pengambilan keputusan suatu kebijakan.
\end{abstract}

Kata Kunci : Globalisasi, Tata Kelola, Transnasionalisme, Ketahanan Dunia

\section{PENGANTAR}

Arus perpindahan manusia secara transnasional, sumber-sumber finansial, barang, jasa, budaya dan informasi telah mengubah dunia secara mendalam (Ritzer \& Malone, 2001 ; Ritzer \& Dean, 2019).
Fenomena tersebut diistilahkan sebagai globalisasi. Globalisasi merupakan tema hangat yang terus menjadi pembahasan dan perdebatan hingga saat ini. Terjadi banyak perdebatan mengenai gagasan globalisasi itu sendiri. Menurut David Held et al (1999), 
globalisasi terdiri dari akumulasi tautan di seluruh kawasan dunia dan di banyak bidang kegiatan. Globalisasi bukanlah suatu proses tunggal namun melibatkan empat tipe perubahan :

Pertama, globalisasi memperluas cakupan kegiatan sosial, politik, dan ekonomi melintasi batas-batas politik, wilayah, dan benua. Kedua, globalisasi mengintensifikasi ketergantungan terhadap satu sama lain, ketika arus perdagangan, investasi, keuangan, migrasi, dan budaya meningkat. Ketiga, globalisasi mempercepat dunia melalui sistem transportasi dan komunikasi baru yang membuat ide, barang, informasi, modal, dan orang bergerak lebih cepat. Keempat, globalisasi membuat peristiwa yang jauh memiliki dampak yang lebih dalam pada kehidupan kita. Bahkan sebagian besar perkembangan lokal mungkin memiliki konsekuensi global yang sangat besar. Batasbatas antara masalah domestik dan urusan global dapat menjadi semakin kabur.

Globalisasi menggambarkan suatu proses transisi menuju suatu masyarakat global yang terintegrasi. Dalam arti lain, dapat dikatakan bahwa globalisasi mendorong terjadinya kepaduan atau tergabungnya suatu masyarakat dunia secara keseluruhan. Gagasan mengenai globalisasi ini mengacu pada proses perubahan sosial, yang pada gilirannya memiliki kemungkinan dalam mempengaruhi perkembangan politik global (Carlsnaes, et al., 2013: 486). Berdasarkan paparan di atas penulis bertujuan untuk menjawab pertanyaan: Bagaimana globalisasi mempengaruhi interaksi politik global? Untuk menjawab pertanyaan tersebut penulis pada bagian-bagian berikutnya, penulis akan membahas dan memberikan pandangan akan membahas keterbatasan dan berbagai perspektif dalam globalisasi untuk masuk ke pembahasan mengenai suatu tata kelola global yang dijelaskan melalui beberapa contoh studi kasus. Dalam melakukan keseluruhan pembahasan dan analisis, pendekatan kualitatif dengan penulisan eksploratif analitis digunakan, dan akan dijelaskan setelah bagian ini. Argumen utama dalam artikel ini yaitu globalisasi menimbulkan bentukbentuk interaksi yang baru dari politik global, seperti hubungan transnasional, yang tidak dapat dilepaskan dari kerangka perspektif teori konstruktivis. Hal tersebut dapat dilihat bahwa aktor non negara seperti organisasi non-pemerintah dan kalangan masyarakat sipil dapat mempengaruhi suatu negara dalam pengambilan keputusan suatu kebijakan.

Dalam artikel ini, penulis akan menggunakan pendekatan kualitatif yang dilakukan dengan penulisan eksploratif analitis. Pendekatan kualitatif digunakan karena cakupannya yang luas dalam penulisan penelitian sosial dan ditujukan untuk menjelaskan, menganalisis, serta memberikan suatu gambaran dan pemahaman terhadap realitas fenomena sosial yang dinamis (Bryman, 2012 ; Neuman, 2014). Menurut Cresswell (2013), suatu penelitian kualitatif dimulai dengan asumsi dan kerangka kerja interpretif yang memberikan informasi terhadap pertanyaan penelitian suatu studi yang membahas mengenai makna individu atau kelompok yang merujuk pada fenomena sosial.

Metode kualitatif digunakan dalam penulisan artikel ini juga karena pembahasan yang dilakukan dalam artikel ini merupakan bagian dari kajian ilmu sosial yang memiliki cross-cutting dalam beberapa studi seperti studi hubungan internasional, studi ketahanan, studi politik dan juga ekonomi. Selain itu, 
dalamera di mana informasi yang sangat cepat berubah mendominasi dunia yang terglobalisasi seperti saat ini, tradisi dan persepsi mengenai konteks dan realitas lokal dan global yang muncul perlu dikaji dalam penelitian ilmu sosial kualitatif.

\section{PEMBAHASAN}

\section{Perdagangan dan Pasar Global}

Pada awal abad ke-20, hampir semua negara-negara bangsa di seluruh dunia mulai membuka perbatasan mereka dalam upaya untuk menjadi lebih kompetitif secara global di pasar internasional. Fenomena tersebut merupakan titik awal munculnya perusahaanperusahaan multinasional. Hingga kini, berbagai perusahaan multinasional tumbuh dan berkembang dalam jumlah luar biasa. Hal tersebut menyebabkan suatu perdagangan bebas di mana ekonomi pasar di abad kedua puluh semakin menyebar dengan proporsi luar biasa di seluruh dunia. Saat ini hampir seluruh negara di seluruh dunia melakukan perdagangan dalam skala internasional. Perdagangan adalah sebuah mekanisme kunci untuk perpindahan barang dan peningkatan jasa, di seluruh dunia, dan merupakan pusat dari transfer teknologi. Dapat dikatakan bahwa pada era sekarang perdagangan merupakan bagian yang tidak dapat dipisahkan dari struktur produksi nasional di seluruh negara modern.

Perdagangan dapat menghubungkan pasar yang jauh. Sebuah jejaring hubungan perdagangan beroperasi membuat kondisi yang untuk memfungsikan pasar global. Ketika peraturan-peraturan perdagangan regional yang terlembagakan telah berevolusi, peraturan-peraturan tersebut cenderung memperkuat tren menuju perdagangan bebas. David Held (1999), berpendapat bahwa globalisasi perdagangan melibatkan lebih dari sekadar pertukaran barang dan jasa antara ekonomi yang terpisah karena perdagangan tersebut menunjukkan munculnya pasar di seluruh dunia untuk barang dan jasa yang diperdagangkan.

Menurut Held (1999) pasar global ada karena ada tingkat yang signifikan dalam pertukaran barang atau jasa yang diatur pada tingkat antar wilayah, di mana ketika hambatan perdagangan, baik dalam bentuk biaya transportasi atau proteksi menurun, dan produsen asing dari satu daerah dapat bersaing dengan produsen domestik di negara lain.

Held mengajukan indikator mengenai globalisasi dengan menggunakan the extensity dari perdagangan dunia untuk merujuk kepada aliran perdagangan antarbenua yang teratur. Data untuk perdagangan antar blok geografis menyediakan sarana untuk menilai apakah ada kecenderungan untuk melihat apakah hal tersebut sebagai suatu regionalisasi atau globalisasi. Regionalisasi mengacu pada evolusi pasar untuk barang-barang yang diperdagangkan yang melibatkan ekonomiekonomi yang berdekatan secara geografis,dan tingkat intensitas perdagangan tersebut jauh lebih besar daripada untuk perdagangan dengan negara lain.

Globalisasi ekonomi dunia telah mempengaruhi dan akan terus mempengaruhi hampir setiap aspek dari urusan domestik dan internasional. Pertumbuhan perdagangan internasional, arus keuangan internasional yang masif, dan kegiatan perusahaan multinasional mengikat ekonomi nasional lebih erat satu sama lain, sehingga menjadikan globalisasi fitur yang penting dan kontroversial dari ekonomi dunia. Meskipun beberapa ekonom terkemuka percaya bahwa keuangan internasional yang tidak diatur menimbulkan ancaman serius bagi 
ekonomi dunia, hampir semua ekonom dan pendukung pasar bebas lainnya percaya bahwa globalisasi menjanjikan dunia yang semakin sejahtera dan kerjasama internasional; mereka berpendapat bahwa boleh terdapat rintangan untuk mencegah arus barang, jasa, dan modal yang bebas.

Perkembangan instrumen keuangan baru, deregulasi pasar keuangan nasional dan pertumbuhan bank internasional dan lembaga keuangan lainnya telah menciptakan suatu sistem keuangan global. Saat ini perdagangan mata uang dan obligasi pemerintah di seluruh dunia berarti bahwa nilai tukar dan suku bunga merupakan dua variabel penting dalam perumusan kebijakan ekonomi makro nasional yang ditentukan dalam konteks pasar keuangan global. Menurut David Held (1999:190) keuangan global mencakup aliran kredit seperti pinjaman, obligasi, investasi, dan nilai tukar mata uang.

Arus keuangan lintas batas telah terjadi selama berabad-abad. Ada banyak cara untuk mengukur ekstensitas dan intensitas keuangan internasional dan berguna di sini untuk membedakan antara keterbukaan keuangan, keterlibatan keuangan, dan integrasi keuangan. Held (1999:189) menyatakan bahwa keterbukaan pasar keuangan nasional mengacu pada tingkat pembatasan hukum pada transaksi keuangan internasional, tingkat keterlibatan keuangan mengacu pada tingkat keterlibatan keuangan nasional suatu negara dalam aktivitas keuangan global, dan integrasi keuangan digunakan dalam arti ekonomi sejauh mana harga, dan pengembalian, aset disamakan antara pasar keuangan nasional yang berbeda.

Dengan memeriksa jangkauan geografis pasar keuangan dunia, kita dapat menilai luasnya keuangan internasional. Menjelajahi besarnya arus keuangan global memberikan wawasan tentang pola historis intensitas globalisasi keuangan. Globalisasi finansial dapat memiliki dampak mendalam pada pelaksanaan kebijakan ekonomi nasional namun dampak tersebut mungkin berbeda di setiap waktu, karena dampak aliran keuangan global juga dipengaruhi secara signifikan oleh kondisi ekonomi nasional (1999:190).

Para pengkritik globalisasi, di sisi lain, meramalkan dunia yang sangat berbeda; mereka takut bahwa peningkatan perdagangan, investasi asing, dan arus keuangan menghasilkan konsekuensi negatif yang kuat bagi masyarakat. Banyak diantara mereka yang membayangkan kemenangan sistem kapitalis kejam yang dicirikan oleh eksploitasi, dominasi, dan ketidaksetaraan yang tumbuh di dalam dan di antara masyarakat domestik. Melalui buku-buku yang ditulisnya mereka menyuarakan dan menyodorkan potret sebuah dunia yang suram dari homogenisasi budaya, komersialisme yang merajalela, dan bahkan kehancuran peradaban Barat. Jajak pendapat publik menunjukkan bahwa setidaknya setengah orang Amerika percaya bahwa globalisasi menurunkan upah domestik, menyebabkan pengangguran, dan memiliki efek berbahaya lainnya. Orang Eropa bahkan lebih skeptis terhadap integrasi ekonomi dunia daripada orang rupa.

\section{Berbagai Perspektif Globalisasi}

Banyak pernyataan dari para pendukung dan penentang globalisasi yang tidak tepat dan berlebihan. Meskipun globalisasi ekonomi memang sangat sedemikian penting, namun dunia hampir tidak terintegrasi secara keseluruhan sebagaimana diyakini banyak pihak, begitu pula globalisasi yang tidak dapat diubah atau dielakkan. Globalisasi 
bersandar pada landasan politik yang dapat gagal jika kekuatan besar gagal memperkuat ikatan ekonomi dan politik mereka. Selain itu, integrasi ekonomi dunia sangat tidak merata, terbatas pada sektor ekonomi tertentu, dan tidak seluas yang diyakini banyak orang. Sebagaimana dicatat oleh beberapa penulis, ekonomi internasional pasca perang hanya memulihkan globalisasi ke tingkat yang kirakira sama pada tahun 1913. The Economist menunjukkan bahwa Prancis dan Inggris tidak lebih terbuka dalam perdagangan di tahun 1999 daripada di tahun 1913, dan begitupula halnya dengan Jepang. Di belahan dunia lain, Pasar Amerika dan Kanada yang semakin terintegrasi pun tetap masih dibatasi secara signifikan oleh perbatasan antara kedua negara. Meskipun teknologi mengarah ke peningkatan globalisasi yang tidak dapat dihindari, kebijakan nasional suatu negara berperan dalam proses globalisasi.

Paul Krugman mencatat bahwa ekonomi dunia pada akhir 1990-an kurang terintegrasi dalam sejumlah hal penting dibandingkan pada sebelum Perang Dunia pertama. Di bawah standar emas dan doktrin laissez-faire yang berpengaruh, misalnya, dekade sebelumnya ke Perang Dunia I adalah era ketika pasar benarbenar berjaya dan pemerintah hanya memiliki sedikit kekuasaan atas berbagai urusan di bidang ekonomi. Dalam kaitannya dengan hubungan ekonomi nasional dan ekonomi internasional, perdagangan, investasi, dan arus keuangan di akhir tahun 1800-an tercatat lebih besar daripada yang terjadi di akhir tahun 1900-an. Selama abad kedua puluh tercatat ada peningkatan besar dalam kecepatan dan besarnya arus keuangan yang melintasi batasbatas nasional; namun dampak ekonomi dari globalisasi tersebut sebagian besar hanya terbatas pada Triad (Amerika Serikat, Eropa
Barat, dan Jepang) dan pasar yang sedang berkembang di Asia Timur. Dan meskipun ekonomi industri telah menjadi jauh lebih terbuka, impor dan investasi yang masuk tetaplah kecil jika dibandingkan dengan ukuran masing-masing ekonomi domestiknya. Integrasi ekonomi di antara negara-negara Triad dalam barang, jasa dan arus keuangan lebih terbatas daripada yang dinyatakan banyak pihak. Batas-batas domestik tetap menjadi penghalang penting bagi arus ekonomi internasional.

Pada pembukaan abad kedua puluh satu, Gilpin (2000) menyatakan bahwa banyak aspek penting dari globalisasi yang bukan merupakan suatu perkembangan baru, dan harus diakui bahwa sebagian besar populasi dunia tidak terlibat dalam globalisasi. Gilpin (2000) juga menyatakan bahwa, terlepas dari kepentingannya, globalisasi ekonomi bersifat terbatas dan tidak mungkin memiliki semua dampak negatif atau positif yang ada di dalamnya.

Dalam ekonomi industri yang bersifat maju, tiga perspektif berbeda muncul dalam perdebatan yang berkembang mengenai globalisasi dan konsekuensinya. Para ekonom, sebagian besar pemimpin bisnis dan politik, dan para pendukung globalisasi lainnya berbagi perspektif «pasar bebas» yang menentang peraturan ketat dalam regulasi ekonomi dunia. Di sisi lain, banyak individu dan kelompok kepentingan seperti serikat pekerja, bisnis-bisnis yang menghadapi persaingan impor, dan ekonom nasionalis berpendapat melalui perspektif «populis». Mereka secara tegas menentang globalisasi dengan mengajukan pembatasan terhadap perdagangan bebas dan kegiatan investor dan perusahaan multinasional. Ada aliran yang bertumpang-tindih dengan perspektif populis, 
namun lebih beraliran politik kiri, yaitu faham «komunitarian»-yang terdiri dari para pecinta lingkungan, pendukung hak asasi manusia, dan pihak-pihak lain yang percaya bahwa globalisasi menciptakan tatanan dunia yang tercemar lingkungannya oleh berbagai polusi, bersifat hirarkis, dan eksploitatif. Kelompokkelompok dengan perspektif komunitarian mendesak adanya tatanan dunia yang bersifat egaliter dan ramah lingkungan.

Dalam konteks globalisasi, perubahanperubahan yang terjadi dalam hubungan antara negara, organisasi internasional dan aktor-aktor non-pemerintah telah mempertanyakan teoriteori yang biasa digunakan dalam hubungan internasional. Perubahan ini sebagian disebabkan oleh meningkatnya interaksi antar negara oleh orang-orang yang tidak mewakili negara. Interaksi yang melintasi batas-batas nasional ketika setidaknya satu aktor yang melakukannya adalah agen non-negara, tidak beroperasi atas nama pemerintah atau organisasi antar pemerintah disebut sebagai hubungan transnasional. Pada era sekarang hubungan transnasional merupakan interaksi yang menembus politik dunia di hampir setiap bidang masalah. Ribuan organisasi nonpemerintah internasional (INGO) - mulai dari International Amnesty dan Greenpeace hingga International Political Science Association - melobi rezim internasional dan organisasi antar negara untuk mencapai tujuan mereka dalam konstelasi politik global.

Dalam konteks ekonomi, Robert Gilpin (2000) berpendapat bahwa globalisasi ekonomi dunia telah mempengaruhi dan akan terus mempengaruhi hampir setiap aspek dari urusan domestik dan internasional. Pertumbuhan perdagangan internasional, arus keuangan internasional yang masif, dan kegiatan perusahaan multinasional mengikat ekonomi nasional lebih erat satu sama lain, sehingga menjadikan globalisasi sebagai fitur yang penting dan kontroversial dari ekonomi dunia. Meskipun beberapa ekonom terkemuka percaya bahwa keuangan internasional yang tidak diatur menimbulkan ancaman serius bagi ekonomi dunia, hampir semua ekonom dan pendukung pasar bebas lainnya percaya bahwa globalisasi menjanjikan dunia yang semakin sejahtera dan kerjasama internasional.

\section{Dinamika Menuju Tata Kelola Global}

Istilah tata kelola global (global governance) di dunia yang semakin terglobalisasi muncul sebagai isu hubungan internasional pada awal tahun 1990. Akademisi dan pembuat kebijakan sering mendiskusikan tentang tata kelola global namun melakukannya dengan suara pasif. Mereka memperlakukan tata kelola sebagai sebuah struktur atau proses. Sugiono (2004) berpendapat bahwa sebagai suatu gagasan yang berawal dari fenomena globalisasi, tata kelola global dapat memiliki tafsir sebagai sebuah konsep yang ekonomistik. Tata kelola global dapat dipahami juga sebagai "jumlah organisasi, instrumen kebijakan, mekanisme pembiayaan, aturan, prosedur, dan norma" atau "upaya kolektif untuk mengidentifikasi, memahami, dan mengatasi masalah di seluruh dunia yang berada di luar kapasitas negara”. Di era globalisasi sekarang ini, secara lebih luas, arena kebijakan global dipenuhi dengan beragam aktor - bukan hanya negara, namun juga organisasi internasional, korporasi, asosiasi profesional, kelompok-kelompok advokasi, dan sejenisnya - yang berupaya untuk "mengatur" aktivitas di bidang isu yang menjadi fokus perhatiannya. Aktor-aktor ini tidak hanya menduduki struktur global. Mereka adalah agen aktif yang menginginkan 
struktur dan aturan baru (atau aturan berbeda) untuk menyelesaikan masalah, mengubah hasil, dan mengubah kehidupan internasional (Finnemore et al, 2010:1). Menurut Held dan McGrew (2002) lanskap sistem internasional, pada faktanya, dihuni oleh semakin banyak organisasi, kantor, dan lembaga-lembaga yang terlibat dalam apa yang disebut tata kelola global (global governance).

Finkelstein mendefinisikan tata kelola global atau global governance sebagai pemerintahan yang mengatur; melakukan dalam lingkup internasional apa yang dikerjakan oleh pemerintah di lingkup nasional (Finkelstein, 1995). Dalam hal ini global governance mempunyai arti yang lebih luas dari Government, di mana aktor negara menjadi sekunder dan timbul aktor global untuk menyelesaikan isuisu International Government atau NonInternational Government. sehingga dapat diartikan bahwa tata kelola global mengacu pada cara di mana urusan global dikelola. Karena tidak ada pemerintahan global, pemerintahan global melibatkan berbagai aktor termasuk negara, serta organisasi regional dan internasional. Dengan demikian global governance membahas mengenai PBB, WTO, IMF, ILO, BIS , G20, konvensi Jenewa dan konvensi-konvensi internasional lainnya, Uni Eropa, dan lain-lain. Sugiono (2005) menyatakan bahwa perkembangan tata kelola global kontemporer memiliki implikasi bagi negara sebagai aktor utama. Negara-negara bukanlah lagi satu-satunya yang menjadi aktor utama dalam konteks tata kelola global.

\section{Perubahan struktur dunia internasional}

Globalisasi, atau pergeseran dalam jangkauan spasial dari aksi gerakan dan organisasi sosial menuju skala ruang antar kawasan, antar benua, atau global, telah mengaburkan korespondensi antara aksi gerakan sosial dan wilayah yang dikelilingi oleh perbatasan negara (Held dan McGrew dalam Finnemore et al, 2010:4). Globalisasi pada umumnya dikaitkan dengan ekonomi global, namun pemahaman mengenai globalisasi telah melampaui masalah ekonomi. Masalah lingkungan, terutama masalah seperti pemanasan global, menjadi perhatian untuk keberlanjutan manusia di dunia. Prasad dan Prasad mendefinisikan globalisasi sebagai sebuah fenomena multidimensi yang mencakup tidak hanya komponen ekonomi tetapi juga budaya, ideologis, politik dan aspek lainnya yang serupa (Prasad dan Prasad, 2006). Menurut Finnemore (2010) Gagasan tentang hak asasi manusia juga telah menjadi platform untuk hubungan sosial antara seluruh manusia di seluruh dunia dan telah berfungsi sebagai pendorong untuk intervensi militer. Bahkan keamanan, dewasa ini, telah diidentifikasikan dengan kemanusiaan, ketika para analis, aktivis, dan negara mengembangkan dan mengimplementasikan konsepsi "keamanan manusia" (Paris dalam Finnemore et al, 2010:6). Sebagai hasilnya, globalisasi dibahas tidak hanya dari sudut pandang ekonomi, namun juga sudut pandang lainnya seperti ilmu sosial, politik dan hubungan internasional. Oleh karena itu globalisasi telah menjadi subyek perdebatan tanpa akhir dalam berbagai disiplin ilmu.

Pandangan klasik mengenai sistem internasional yang berpusat pada negara tidak menangkap perubahan-perubahan yang telah dijelaskan pada paparan di atas. Sementara asumsi-asumsi fungsionalis hanya memberikan pemahaman terbatas untuk memahami dinamika pemerintahan atau tata kelola global aktual yang terjadi di dunia 
saat ini. Penulis berargumen paparan diatas menunjukkan bahwa baik pendekatan "statist" atau "klasik" maupun "fungsional" tidak memadai untuk memahami tata kelola global pada masa ini.

Istilah "Tata kelola global" menggambarkan berbagai kegiatan pembuatan kebijakan yang menghasilkan tindakan terkoordinasi tanpa adanya satu pemerintahan dunia (Finnemore et al, 2010:14). Tata kelola global tidak terbentuk secara alami atau lancar menuju suatu keseimbangan. Tata kelola adalah hasil dari proses politik dan dibentuk oleh kekuasaan, akses, mobilisasi, kepemimpinan, dan variabel politik lainnya. Variabel-variabel politik ini penting untuk menentukan apa yang diperhatikan sebagai masalah global serta solusi mana yang dipilih untuk mengatasinya (Finnemore et al, 2010:7)

Finnemore et al (2010:31) menggunakan kerangka kerja konseptual yang didasarkan pada hubungan otoritas penata kelola dan yang dikelola serta hubungannya satu sama lain. Dengan menyelidiki secara sistematis otoritas para aktor tersebut, akan didapatkan pemahaman yang lebih baik tentang dari mana para penata kelola ini berasal, bagaimana dan mengapa mereka dapat mempengaruhi kebijakan, dan bagaimana mereka bisa gagal atau ditantang. Dengan melihat hubungan antar penata kelola, akan terpapar suatu jaringan kompleks (inter) dependensi, tidak hanya antara penata kelola dan yang dikelola, namun juga di antara penata kelola tersebut sendiri, Oleh karena itu, penulis berargumen bahwa, untuk memahami tata kelola global, perlu untuk meninjau transformasi negara secara domestik dan perubahan struktur internasional di mana kedua hal tersebut dapat menjadi mode dominan di mana tata kelola global dibangun saat ini.
Sejak era Perang Dingin berakhir, para pengkaji hubungan internasional telah mempertanyakan kembali mengenai pendekatanpendekatan yang biasa digunakan dalam kajian hubungan internasional. Hal tersebut disebabkan karena meningkatnya interaksi antar negara oleh orang-orang atau institusi-institusi yang tidak mewakili negara dalam interaksi internasional, khususnya dalam konteks globalisasi seperti saat ini. Interaksi tersebut didefinisikan oleh Thomas Risse-Kappen pada tahun 1995 dalam bukunya Bringing Transnational Relations Back in: Non-state Actors, Domestic Structures and International Institutions sebagai hubungan transnasional. Hubungan transnasional adalah interaksi yang melintasi batas-batas nasional ketika setidaknya satu aktor yang melakukannya adalah agen non-negara, tidak beroperasi atas nama pemerintah atau organisasi antar pemerintah (Risse-Kappen, 1995:3).

\section{Hubungan Transnasional}

Untuk memahami dan dapat melihat lebih lanjut mengenai tata kelola global, menurut penulis, perlu untuk meninjau kembali literatur-literatur yang menjelaskan mengenai hubungan transnasional. RisseKappen (1995:6) berpendapat bahwa struktur domestik memiliki dampak besar pada akses dan pengaruh sistem politik dari luar sistem tersebut. Keck dan Sikking (1998:4) menyatakan bahwa, bahkan teori liberal tentang hubungan internasional mengakui bahwa kepentingan domestik membentuk tindakan negara secara internasional, dan bahwa negara tertanam dalam dunia yang saling tergantung di mana aktor non-negara menjadi konsekuen.

Peter J. Katzenstein dan Yutaka Tsujinaka (dalam Risse Kappen, 1995) mengambil hubungan transnasional Amerika 
Iskandar Hamonangan -- Pasar, Tata Kelola Dan Hubungan Transnasional Di Era Globalisasi Dan Implikasinya Terhadap Ketahanan Politik Dunia

Serikat dan Jepang dalam konteks isu perdagangan dan keamanan sebagai studi kasus, dan menjelaskan bagaimana hubungan transnasional penting dalam politik dunia kontemporer. Struktur domestik menciptakan dorongan yang membentuk perilaku politik aktor pemerintah dan non-pemerintah di dunia internasional (1995:109).

Perusahaan multinasional atau multinational companies (MNC) merupakan agen transnasional yang penting dalam ekonomi politik global kontemporer (Clark dan Chan dalam Risse Kappen, 1995:112). Cal Clark dan Steve Chan menyimpulkan bahwa budaya politik suatu negara dan hubungan negara dan masyarakatnya memiliki pengaruh yang menentukan sejauh mana MNC dapat memiliki akses. Baik budaya politik dan hubungan negara-masyarakat merupakan aspek penting dari struktur domestik (1995:144). Paparan Clark dan Chan mendukung hipotesis Risse-Kappen tentang hubungan antara kekuasaan negara dan akses transnasional. Secara umum, kerangka kerja yang dipaparkan Crark dan Chan menjelaskan bahwa perusahaan multinasional memiliki akses yang lebih terbatas dalam sistem yang didominasi negara. Pandangan ini berlaku untuk perbandingan India dan Korea Selatan, di satu sisi, dengan Hong Kong dan Filipina, di sisi lain. Namun, jika negara kuat bersedia untuk mengizinkan akses secara sukarela, Risse-Kappen memperkirakan bahwa dampak aktor transnasional bisa sangat besar. Konteks ini, menggambarkan situasi di Singapura di mana MNC memainkan peran yang jauh lebih besar daripada di tempat lain di Asia (1995:145).

Selanjutnya, Thomas Princen (dalam Risse-Kappen, 1995) membahas mengenai peran dan proses penting Environmental
Transnational Coalitions (ETC) dalam advokasi konservasi dan lingkungan di ranah domestik dan internasional. Konsensus yang berkembang muncul dalam komunitas konservasi internasional yaitu mengakui bahwa solusi untuk masalah lingkungan global seperti hilangnya spesies harus disesuaikan dengan kondisi di tingkat ekosistem dan komunitas lokal serta menghubungkannya dengan manajemen ekonomi lokal dan global (1995:252).

Di Indonesia saat ini aktor non-negara juga aktif dalam mendorong aktor-aktor lainnya dalam mengambil suatu kebijakan. Bestari (2018) dalam penelitiannya telah membahas mengenai advokasi hak pekerja rumah tangga sebagai pekerja formal di Indonesia. Advokasi oleh organisasi-organisasi non-pemerintah Indonesia tentang hak-hak pekerja rumah tangga memasuki dimensi transnasional ketika peneliti Human Rights Watch melakukan penelitian etnografi tentang kondisi pekerja rumah tangga di Indonesia. Sejalan dengan Human Rights Watch, sejumlah organisasi non-pemerintah internasional mulai menyuarakan kritiknya terhadap praktik hukum yang berlaku di Indonesia kepada pemerintah Indonesia (Bestari, 2018). Selain itu, Virgyet al (2020) membahas mengenai Greenpeace Indonesia yang menekan Wilmar Internasional sebagai pelaku deforestasi di Indonesia. Greenpeace Indonesia berhasil mendorong Wilmar International untuk mengubah perilakunya dan berkomitmen mengimplementasikan kebijakan No Deforestation, No Peat, No Exploitation (NDPE), melalui pembentukan jaringan advokasi transnasional yang membuatnya memiliki cukup power dalam upaya menekan Wilmar International. Dalam penelitian tersebut, dapat terlihat interaksi antara aktor 
non-negara satu dengan lainnya serta dengan organisasi regional dalam skala internasional seperti Uni Eropa. Greenpeace Indonesia yang dalam interaksi-interaksinya menggunakan empat strategi dari Keck and Sikkink (1998), yaitu: Information Politics, Symbolic Politics, Leverage Politics, Accountability Politics sebagai bentuk dari political move dengan aktor internasional lainnya.

Konsep transnasionalisme mengacu pada berbagai ikatan dan interaksi yang menghubungkan orang-orang dan lembagalembaga lintas batas negara-bangsa. Aktivitas transnasional dapat didefinisikan sebagai:

"Mereka yang terjadi secara berulang melintasi perbatasan nasional dan yang memerlukan komitmen waktu yang signifikan dan signifikan oleh para peserta. Kegiatan semacam itu dapat dilakukan oleh para aktor yang relatif kuat, seperti perwakilan pemerintah nasional dan perusahaan multinasional, atau dapat diprakarsai oleh individu-individu yang lebih sederhana, seperti imigran dan kerabat serta hubungan negara asalnya. Kegiatan-kegiatan ini tidak terbatas pada perusahaan ekonomi, tetapi juga termasuk inisiatif politik, budaya dan agama" (Portes, 1999).

Definisi ini menunjukkan hubungan erat antara transnasionalisme dan globalisasi, yang pada dasarnya juga merujuk pada ekspansi cepat transaksi dan jaringan lintas batas di semua bidang kehidupan. Pada saat yang sama, konsep tersebut menunjukkan bahwa batas-batas antara negara-bangsa telah menjadi kabur. Menurut Winanti (2002), kedaulatan suatu negara bangsa tidak lagi dapat didefinisikan terbatas berdasarkan pada kontrol atas batas-batas territorial tertentu, namun perlu dipandang dari sisi yang lebih fungsional terhadap jaringan transnasional yang kompleks.
Komunitas transnasional adalah salah satu aspek dari transnasionalisme. Komunitas transnasional adalah kelompok yang identitasnya tidak mengutamakan pada keterikatan pada wilayah tertentu. Gagasan tentang komunitas transnasional menekankan pada agensi manusia, yang memandang kelompok-kelompok tersebut adalah hasil dari kegiatan lintas batas yang menghubungkan individu, keluarga dan kelompok lokal.

Bersama-sama dengan globalisasi, peningkatan tajam komunitas-komunitas transnasional melemahkan sarana untuk mengendalikan perbedaan yang dibangun berdasarkan kewilayahan. Komunitas transnasional merupakan tantangan yang kuat untuk ide-ide tradisional milik negara-bangsa (Castles, 2000). Gagasan atas seseorang yang hanya memiliki satu negara-bangsa atau paling banyak bermigrasi dari satu negara ke negara lain (baik sementara atau permanen) telah digeser oleh peningkatan mobilitas; pertumbuhan migrasi temporer dengan siklus yang berulang; serta perjalanan yang murah dan mudah. Dalam konteks globalisasi, transnasionalisme dapat memperluas komunitas tatap muka sebelumnya berdasarkan kekerabatan, lingkungan atau tempat kerja ke komunitas virtual terpencil, melalui komunikasi dari jarak yang jauh.

Komunitas transnasional tidak hanya merujuk pada migran, karena berbagai kelompok lintas batas dengan kepentingan yang sama di bidang budaya, olahraga, politik atau lainnya, juga menganggap diri mereka sebagai suatu komunitas. Namun, secara praktis, kelompok-kelompok yang muncul dari migrasi adalah tipe yang paling signifikan, dan sebagian besar penelitian-penelitian tentang komunitas transnasional merujuk pada hal tersebut. Hal tersebut jelas dapat dilihat 
Iskandar Hamonangan -- Pasar, Tata Kelola Dan Hubungan Transnasional Di Era Globalisasi Dan Implikasinya Terhadap Ketahanan Politik Dunia

karena, para migran selalu hidup di lebih dari satu lingkungan, memelihara hubungan dengan komunitas nyata atau imajiner di negara asal. Hal yang bergeser adalah konteks globalisasi dan ketidakpastian ekonomi yang memfasilitasi pembangunan hubungan sosial yang melampaui batas negara. Peningkatan mobilitas dan perkembangan komunikasi telah berkontribusi pada hubungan-hubungan semacam itu, dan telah menciptakan ruang transnasional dari partisipasi ekonomi, budaya dan politik.

Dalam kajian-kajian mengenai hubungan transasional, banyak pembahasanpembahasan yang tidak hanya berbicara mengenai perusahaan multinasional. Held (1991) menyatakan bahwa politik internasional saat ini dibentuk oleh beragam aktor ketika negara berinteraksi dalam politik dunia dengan individu, masyarakat sipil, organisasi internasional dan organisasi nonpemerintah internasional (INGO). Interaksi antara entitasentitas tersebut seringkali terstruktur dalam bentuk jejaring (Castells, 1996; Keck dan Sikkink, 1998). Hubungan transnasional dalam kajiannya juga membahas mengenai istilah jejaring advokasi transnasional (transnational advocacy network). Istilah jejaring advokasi transnasional menurut Ani Soetjipto dalam bukunya "Transnasionalisme: Peran Aktor Non Negara Dalam Hubungan Internasional" (2018:27) melibatkan pengorganisasian yang bersifat lintas nasional dan melibatkan kekuatan massa yang terorganisasi maupun tidak terorganisasi dalam memperjuangkan beragam isu serta memiliki beragam ideologi dan strategi perjuangan. Jejaring advokasi transnasional merujuk kepada kelompok advokasi mandiri yang bekerja secara sukarela dan melintasi batas negara untuk mencapai kepentingan yang mereka anggap akan merepresentasikan kepentingan publik yang lebih luas (2018:36). Sedangkan jejaring (network) menurut Keck dan Sikkink adalah berbagai bentuk pengorganisasian yang bersifat sukarela, timbal balik, dan memiliki pola horizontal dalam pertukaran dan komunikasinya (Keck \& Sikking, 1998: 8).

Gambar 1

Pola Bumerang (boomerang pattern)

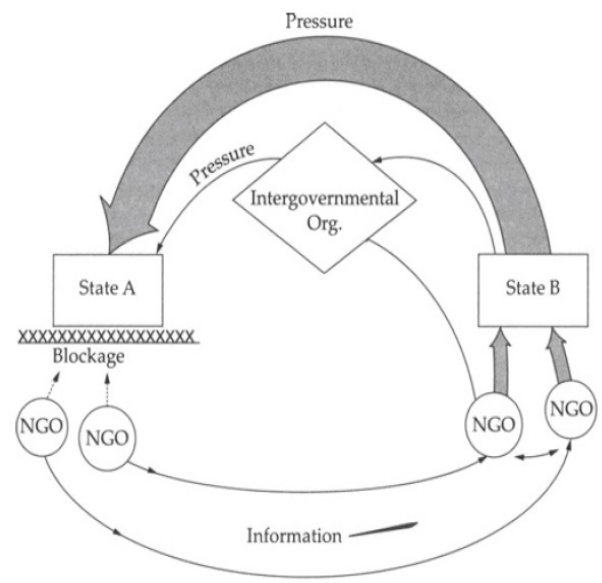

Sumber: (Keck \& Sikking, 1998:12).

Gambar 1 menunjukkan "Pola Bumerang" yang menjadi karakteristik dari jaringan transnasional. Jika negara A memblokir organisasi-organisasi yang berada di dalam negaranya tersebut, maka mereka akan mengaktifkan jaringan di negara B yang para anggotanya menekan negara mereka sendiri (negara B) dan organisasi pihak ketiga, yang menekan negara A (Keck \& Sikking, 1998:12).

Perspektif transnasional dalam penelitian berarti menggeser unit analisis dari masing-masing negara ke sistem global. Objek penyelidikan sosiologi, dan kontribusi mendasarnya, dalam studi transnasional adalah studi tentang "struktur sosial transnasional". Pergeseran seperti itu berarti menempatkan bentuk-bentuk pemerintahan non-negara di bidang hubungan internasional yang 
ada dan baru muncul. Nye dan Keohane (1971) berpendapat bahwa transnasionalisme mempengaruhi beragam bidang pemerintahan internasional termasuk politik antar negara, nilai-nilai, kebijakan luar negeri AS, dan organisasi internasional. Sumber-sumber pemerintahan non-negara dapat berkembang dari gerakan sosial dan organisasi masyarakat sipil yang ada dan baru muncul.

Perspektif transnasional memberikan pemahaman yang lebih mendalam ke dalam sejumlah proses sosial, ekonomi, dan politik kontingen global termasuk gerakan sosial, pemerintahan dan politik, terorisme, kekerasan politik, dan kejahatan terorganisir di antara yang lainnya. Salah satu bidang studi yang paling berhasil adalah migrasi transnasional. Penelitian di bidang ini membahas masalah-masalah seperti interaksi yang menonjol dengan lembaga masyarakat penerima, kebijakan migrasi negara, peran diskriminasi dalam membatasi akses ke lembaga masyarakat sipil masyarakat penerima, akses ke komputer di rumah dan masyarakat penerima, dan biaya serta kesulitan lain yang memengaruhi kelompok migran (Kivisto, 2001). Agenda penelitian yang berkembang menyangkut munculnya masyarakat sipil, negara, dan organisasi non-negara, yang dikembangkan untuk menanggapi masalah imigrasi transnasional. Identitas terus ditantang oleh karakterisasi hukum dan sosial yang lancar dari para migran yang dibuat dan disesuaikan dengan organisasi lokal, nasional, dan internasional.

Untuk menjelaskan fenomena transnasionalisme dalam hubungan internasional, perlu dilihat bahwa paham konstruktivisme memiliki pengaruh dalam hubungan internasional. Teori tentang norma dalam hubungan internasional sering didefinisikan sebagai standar perilaku yang pantas untuk aktor. Norma dapat memiliki peran penting dan bersifat otonom untuk dapat mendebat sistem politik internasional, apa pun itu sistemnya. (2018:31). Keyakinan bersama yang sama atas norma, nilai, prinsip, atau ide mengikat jejaring transnasional dalam advokasinya untuk mempengaruhi politik internasional (Keck \& Sikking dalam Soetjipto, 2018: 37).

\section{Efek dan Keberhasilan Hubungan Transnasional}

Menurut Thomas Risse-Kappen (1995), hubungan transnasional tampak tidak memiliki efek yang sama dalam setiap kasus. Keohane dan Nye (1972) dalam artikelnya, Transnational Relations and World Politics: An Introduction menawarkan 5 efek yang dapat dibawa oleh interaksi atau hubungan transnasional: 1) Interaksi transnasional dapat mendorong perubahan sikap yang mungkin memiliki konsekuensi terhadap kebijakan suatu negara,2) Promosi pluralisme internasional dengan terhubungnya suatu kelompok kepentingan domestik dalam struktur transnasional, 3) Peningkatan hambatan pada negara melalui dengan munculnya "dependence" dan "interdependence", 4) Peningkatan kemampuan pemerintah tertentu untuk mempengaruhi yang lain, Keohane dan Nye menyatakan bahwa pemerintah sering berusaha memanipulasi interaksi transnasional sebagai usaha untuk mencapai hasil politis, seperti dengan menggunakan wisatawan sebagai mata-mata atau penanaman kelompok etnis atau agama yang bersimpati di negaranegara lain. Hal tersebut menurut Keohane dan Nye adalah contoh dari "penetrasi informal", dan 5) Munculnya aktor otonom dengan kebijakan luar negeri yang bersifat privat 
dan mungkin tidak sejalan dengan kebijakan negara.

Risse-Kappen (1995) membangun dan mengintegrasikan dua pendekatan teoritis yang dikembangkan secara independen satu sama lain dan jarang disatukan dalam penelitian hubungan internasional untuk memahami hubungan transnasional, yaitu konsep struktur domestik dan institusi internasional. Kedua stuktur tersebut merupakan struktur yang berurusan dengan stuktur pemerintahan. Risse-Kappen (1995:6) berpendapat bahwa dampak aktor transnasional dan koalisi pada kebijakan negara cenderung bervariasi sesuai dengan perbedaan dalam struktur domestik, yaitu, pengaturan normatif dan organisasional yang membentuk "negara," struktur masyarakat, dan menghubungkan keduanya dalam pemerintahan dan derajat pelembagaan internasional, yaitu, sejauh mana isu spesifik di suatu area diatur oleh perjanjian bilateral, rezim multilateral, dan / atau organisasi internasional.

Risse-Kappen berpendapat bahwa struktur domestik memiliki dampak besar pada akses dan pengaruh sistem politik dari luar sistem tersebut. Keck dan Sikking (1998) menambahkan bahwa, bahkan teori liberal tentang hubungan internasional mengakui bahwa kepentingan domestik membentuk tindakan negara secara internasional, dan bahwa negara tertanam dalam dunia yang saling tergantung di mana aktor non-negara menjadi konsekuen. Risse-Kappen (1995:21) memperhitungkan tiga pilar aspek struktur domestik. Aspek pertama terdiri dari sifat terpusat atau terfragmentasi dari lembagalembaga politik negara. Aspek kedua adalah struktur masyarakat, dalam arti bahwa masyarakat yang kuat ditandai oleh tidak banyaknya perpecahan sosial, lebih peka terhadap politik dan lebih mudah termobilisasi. Aspek ketiga adalah jaringan kebijakan antara negara dan masyarakat, seperti partai politik sebagai lembaga perantara yang kuat, yang kehadirannya dapat memfasilitasi perubahan. Sejauh mana organisasi perantara seperti partai politik mengumpulkan tuntutan masyarakat dan menyalurkannya ke dalam proses politik? Apakah budaya politik menekankan pada pengambilan keputusan konsensual atau lebih tepatnya perundingan dan perselisihan yang distributif dalam jaringan kebijakan? Kebijakan konsensual kemudian akan ditandai oleh organisasi perantara yang kuat yang beroperasi dalam budaya pengambilan keputusan yang berorientasi pada kompromi, sementara pemerintah yang terpolarisasi akan menekankan perundingan distributif, yang seringkali mengarah pada blokade dalam pengambilan keputusan (1995:22). Lembagalembaga internasional juga merupakan kunci bagi dampak kebijakan aktor transnasional; mereka tidak hanya memfasilitasi pembentukan koalisi trans-pemerintah tetapi para aktor transnasional yang bekerja di lembagalembaga internasional mendapatkan akses yang lebih mudah ke pemerintah negaranegara anggota. (1995:31)

\section{SIMPULAN}

Globalisasi merupakan suatu proses transisi menuju suatu masyarakat global yang terintegrasi. Dalam arti lain, dapat dikatakan bahwa globalisasi mendorong terjadinya kepaduan atau tergabungnya suatu masyarakat dunia secara keseluruhan. Globalisasi dapat dilihat melalui berbagai perspektif. Dalam konteks pasar, globalisasiditandai dengan munculnya suatu integrasi pasar yang memperlihatkan signifikansi pertukaran barang atau jasa yang diatur pada tingkat antar 
wilayah, dan turunnya berbagai hambatan perdagangan, baik dalam bentuk biaya transportasi atau proteksi lainnya, serta produsen asing dari satu daerah dapat bersaing dengan produsen domestik di negara lain.

Globalisasi pada umumnya dikaitkan dengan ekonomi global, namun pemahaman mengenai globalisasi telah melampaui masalah ekonomi. Globalisasi juga melibatkan isuisu seperti lingkungan, pemanasan global, bahkan hak asasi manusia, yang melibatkan tidak hanya negara sebagai aktor, namun juga aktor-aktor non negara seperti organisasi nonpemerintah dan masyarakat sipil. Interaksi yang melibatkan setidaknya satu aktor yang bukan merupakan agen non-negara, tidak beroperasi atas nama pemerintah atau organisasi antar pemerintah disebut sebagai hubungan transnasional. Penulis melihat bahwa dalam memandang efek hubungan atau interaksi transnasional, Keohane dan Nye tetap menempatkan pemerintah atau negara sebagai unsur yang paling penting meskipun dapat mendorong perubahan terhadap kebijakan suatu negara. Untuk menganalisa faktor kesuksesan hubungan transnasional RisseKappen juga menggunakan pemerintah sebagai instrumen. Risse-Kappen membangun pendekatan teoritis melalui struktur domestik dan institusi internasional untuk melihat faktor keberhasilan hubungan transnasional yang berurusan secara independen satu sama lain dengan struktur sistem pemerintahan. Melalui dua pendekatan teoritis tersebut, Risse-Kappen menawarkan suatu gambaran bahwa di bawah kondisi internasional yang serupa, perbedaan dalam struktur domestik menentukan variasi dalam dampak kebijakan aktor transnasional.

Selain itu penulis melihat bahwa globalisasi memiliki pengaruh dan telah membentuk interaksi-interaksi politik global yang baru. Hal tersebut dapat dilihat bahwa aktor non negara seperti organisasi nonpemerintah dan kalangan masyarakat sipil dapat mempengaruhi suatu negara dalam pengambilan keputusan suatu kebijakan.

\section{DAFTAR PUSTAKA}

Berlie, Jean A. (2020). China's Globalization and The Belt and Road Initiative. London: Palgrave MacMillan.

Bestari, Gema Ramadhan. (2018). Domestic Worker, Transnational Advocacy and the State of Exception: A Case Study on The Advocacy of Domestic Worker's Rights in Indonesia. Politik Indonesia: Indonesian Political Science Review 3 (1), January 2018, pp. 37-54.

Bryan, L.\&Farrel, D. (1996). Market Unbound: Unleashing Global Capitalism. John Wiley \& Sons. Inc.

Bryman, Alan. (2012). Social Research Methods (4 ${ }^{\text {th }}$ edition). New York: Oxford University Press.

Castells, M. (1996). The information age: economy, society and culture. Vol. I, The rise of the network society. Blackwell, Malden, Mass.

Castles, S. (2000). International Conference on Transnational Communities in the Asia Pacific Region: Comparative Perspectives. Singapore 7-8 August, 2000.

Creswell, John W. (2013). Qualitative Inquiry and Research Design: Choosing Among Five Approaches. New York: Sage Publications.

Drucker, P.F. (1997). The Global Economy and the Nation State, Foreign Affairs, September/October.

Finkelstein, LS. (1995). What is global governance?. Global Governance Vol. 1, No. 3 (Sept.-Dec. 1995), pp. 367-372. 
Iskandar Hamonangan -- Pasar, Tata Kelola Dan Hubungan Transnasional Di Era Globalisasi Dan Implikasinya Terhadap Ketahanan Politik Dunia

Finnemore, Martha \& Susan K, Sell. (2010). Who Governs the Globe?. Cambridge: Cambridge University Press.

Gilpin, Robert. (2000). The Challenge of the World Global Economy Capitalism in the $21^{\text {st }}$ Century. Princeton University Press.

Held, D. (1991). Democracy, the nation-state and the global system. Economy and society, 20:2, 138-172.

Held D., McGrew A., Goldblatt D. \& Perraton J. (1999), Global tranformations. Politics, Economics and Culture, Polity Press, Cambridge.

Held D., McGrew A. (2002).Governing Globalization: Power, Authority, and Global Governance. Cambridge: Polity Press.

Held, D. \& McGrew, A. (2003). The Global Transformations Reader: An Introduction to the Globalization Debate (Eds.). Cambridge: Polity Press.

Rodrik, Dani. (1997). Has Globalisation Gone Too Far. Institute for International Economics.

Kastoryano, R. (2000). Settlement, transnational communities and citizenship. International Social Science Journal. Vol 165 , September 2000. Blackwell Publishers/ UNESCO

Keck, M. \& Sikkink, K. (1998). Activists Beyond Borders. New York: Cornell University Press.

Keck, M. E., \& Sikkink, K. (1999). Transnational Advocacy Network in Internasional Relations and Regional Politics. Oxford: Blackwell Publisher.

Keohane, R. \&Nye, J. (1972). Transnational Relations and World Politics: An Introduction. International Organisation, 25 (3) 3 (summer).
Kivisto, Peter. (2001). Theorizing Transnational Migration: A Critical Review of Current Efforts. Ethnic and Racial Studies 24(4): 549-577.

Neuman, W Laurence. (2014). Social Research Methods: Qualitative and Quantitative Approaches ( $7^{\text {th }}$ edition). London:Pearson Education Limited.

Portes, A. (1999). Conclusion: towards a new world - the origins and effects of transnational activities. Ethnic and Racial Studies 22(2): 463-77.

Prasad, A., \& Prasad, P. (2006). Global transitions:The emerging new world order andits implications for business and management. Business Renaissance Quarterly, 1(3):91-113.

Risse-Kappen, Thomas. (1995). Bringing Transnational Relations Back in: Nonstate Actors, Domestic Structures and International Institutions. Cambridge University Press.

Ritzer, G., \& Malone, E. (2001). Globalization theory: Lessons from the exportation ofMcDonaldization and the new means of consumption, in G. Ritzer (Ed.), Explorationsin the sociology of consumption. Sage Publications: Thousand Oaks, pp.160-180.

Ritzer, G., \& Dean, P. (2019). Globalization: The Essentials, 2nd Edition. WileyBlackwell

Robinson, William I. (1998). 'Beyond NationState Paradigms: Globalization, Sociology, and the Challenge of Transnational Studies,' in Sociological Forum 13(4).

Robinson, William I. (2004). A Theory of Global Capitalism: Production, Class, and State in a Transnational World. Baltimore, Maryland: Johns Hopkins University Press. 
Sikkink, Kathryn. (1998). Transnational Politics, International Relations Theory, and Human Rights. PS: Political Science and Politics 31(3): 516-523.

Soetjipto, Ani. (2018). Transnasionalisme: Peran Aktor Non-Negara dalam Hubungan Internasional. Jakarta: Yayasan Pustaka Obor Indonesia.

Stubbs. Richard I Underhill., Geoffrey R.D. (1994). Political Economy and the Changing Global Order. eds. Canadian Journal of Political Science. Toronto: McClelland and Stewart, 1994, pp. vii, 553.

Sugiono, Muhadi. (2004). Global Governance sebagai Agenda Penelitian dalam Studi Hubungan Internasional. Jurnal Ilmu Sosial dan Politik, Vol 8, No 2: 197-212.

Sugiono, Muhadi. (2005). Globalisasi, 'Global Governance'dan Prospek 'Governance' di Dunia Ketiga. Jurnal Ilmu Sosial dan Politik, Vol 8, No 3: 249-262.

Vertovec, S. (1999). Conceiving and researching transnationalism. Ethnic and Racial Studies 22(2): 445-62. dalam Castles, S. 2000. International Conference on Transnational Communities in the Asia Pacific Region: Comparative Perspectives. Singapore 7-8 August, 2000.

Vertovec, Steven. (2001). Transnationalism and Identity. The Journal of Ethnic and Migration Studies 27(4): 573-582.
Virgy, Muhammad A., Djuyandi, Yusa., \& Wawan Budi D. (2020). Strategi Jaringan Advokasi Transnasional Greenpeace Indonesia Terkait Isu Deforestasi Hutan Indonesia oleh Wilmar International. Journal of Political Issues Volume. 1, Issues. 2, Januari 2020, pp. 74-91.

Wendt, Alexander. (1992). Anarchy is what States Make of it: The Social Construction of Power Politics. International Organization Vol. 46, No. 2.

Wendt, Alexander. (1995). "Constructing International Politics". International Security, Vol. 20.

Wendt, Alexander. (1999). Social Theory of International Politics. Cambridge Studies in International Relations.

Wibisono, Ali. (2018). Konstruktivisme Dalam Ilmu Hubungan Internasional. Presentasi Kuliah Teori Hubungan Internasional. Universitas Indonesia.

Willis, Catherine. (2005). Transnational Theory. Institute for Research and Debate on Governance.

Winanti, Poppy S. (2002). Globalisasi dan Negara Bangsa : Kompetisi Perspektif Globalis Dan Skeptis Dalam Studi Hubungan Internasional. Jurnal Ketahanan Nasional UGM, VI (1), April 2002. 